\title{
Aderența la tratamentul antiretroviral a gravidelor infectate cu HIV-1 în copilăria mică
}

\author{
Eugenia-Andreea Marcu ${ }^{1,2}$, Mariana Stănescu ${ }^{1,2}$, Costin Berceanu ${ }^{1,3}$, \\ Florentina Dumitrescu ${ }^{1,2}$ \\ ${ }^{1}$ Universitatea de Medicină și Farmacie, Craiova, România \\ ${ }^{2}$ Spitalul Clinic de Boli Infecțioase și Pneumoftiziologie „Victor Babeș", Craiova, România \\ ${ }^{3}$ Spitalul Clinic Județean de Urgență, Craiova, România
}

\begin{abstract}
REZUMAT
Obiective. Evaluarea nivelului aderenței la terapia antiretrovirală combinată (TARVc) a gravidelor infectate cu HIV-1 în copilăria mică, aflate în evidența Centrului Regional de Monitorizare și Evaluare a Infecției HIV/ SIDA din cadrul Spitalului de Boli Infecțioase și Pneumoftiziologie „Victor Babeș“ Craiova (CRC) și identificarea principalilor factori asociați cu nonaderența.

Material și metodă. Studiu retrospectiv, în perioada 01 ianuarie 2014 - 31 decembrie 2019, analizând datele consemnate în documentele medicale ale gravidelor HIV pozitive aflate în evidența CRC.

Nivelul aderenței la TARVc a fost apreciat după aplicarea unui chestionar de aderență: 18-22 puncte (aderență $\geq 80 \%$ ) și sub 18 puncte (nonaderență < 80\%).

Rezultate. Grupul studiat a cuprins 71 de paciente și a fost divizat în două loturi, în functie de calea de infectare cu HIV: lotul A, ce a cuprins 48 de gravide infectate cu HIV pe cale parenterală, în copilăria mică, și lotul $B$, ce a cuprins 23 de gravide infectate cu HIV pe cale sexuală.

Am constatat că proporția de paciente nonaderente la TARVc a fost mai mare în cadrul pacientelor infectate cu HIV pe cale sexuală $(77,7 \%)$, comparativ cu cele infectate parenteral, în copilăria mică $(14,8 \%)$, cu diferențe semnificative statistic $(p=0,001)$. A existat o corelație înalt semnificativă statistic între nivelul viremiei HIV și nivelul aderenței la TARVc $(p=0,005)$.

Concluzii. Gravidele infectate cu HIV-1 în copilăria mică au avut un nivel crescut al aderenței, comparativ cu cele infectate pe cale sexuală, direct corelat cu viremia HIV.
\end{abstract}

Cuvinte cheie: HIV, aderență, parenteral, copilăria mică

\section{INTRODUCERE}

La nivel global, la sfârșitul anului 2019, numărul femeilor infectate cu virusul imunodeficienței umane (HIV) era de 19,6 milioane. Dintre acestea, aproximativ 1,4 milioane nasc anual, iar $82 \%$ primesc terapie antiretrovirală combinată (TARVc) (1).

TARVc la gravida infectată cu HIV trebuie să se axeze pe reducerea transmiterii perinatale a infecției și pe împiedicarea evoluției bolii materne (2).

TARVc poate reduce transmiterea perinatală a infecției cu HIV prin scăderea încărcăturii virale materne antepartum și profilaxia preexpunere a nounăscutului (3).

În țările cu venituri ridicate, implementarea TARVc a redus rata transmiterii materno-fetale la mai puțin de $1-2 \%$, fiind raportate rate extrem de mici în rândul femeilor aflate sub TARVc în momentul concepției (de exemplu, 0,2\% în Franța din 2000 până în 2010). În țările cu venituri medii și mici, studiile clinice au evidențiat rate de transmitere materno-fetală mai mici de 5\% (4-6).

Ca parte a efortului de a elimina transmiterea verticală a infecției cu HIV, Organizația Mondială a 
Sănătății (OMS) a introdus în 2010 două strategii de prevenire a transmiterii materno-fetale, opțiunea A și opțiunea B. În cadrul opțiunii A, au fost prescrise două regimuri antiretrovirale, distincte, pentru femeile însărcinate sau care alăptează, în funcție de statusul clinico-imunologic, în timp ce, în cadrul opțiunii B, tripla terapie antiretrovirală este prescrisă tuturor gravidelor HIV pozitive sau celor care alăptează (7).

Pentru selectarea terapiei, se iau în considerare: profilul de siguranță, efectele adverse posibile, frecvența în administrare, lipsa teratogenității, viremia HIV la inițiere, pragul genotipic de rezistență, comorbiditățile mamei, prezența HLA B 5701 (8). Modificările fiziologice apărute în timpul sarcinii (expansiunea volemică, modificările gastro-intestinale, enzimatice și hormonale) pot afecta, de asemenea, proprietățile farmacocinetice ale antiretroviralelor și pot duce la alterarea absorbției, reducerea legării de proteinele plasmatice și eliminare crescută (9).

Pacientele aflate în TARVc anterior sarcinii trebuie să continue aceeași terapie dacă aceasta este eficientă, menține supresia virală susținută și nu cuprinde medicamente contraindicate în sarcină (8).

În timp ce TARVc a îmbunătățit tot mai mult starea clinică a gravidelor HIV pozitive, atenția este concentrată tot mai mult pe rolul aderenței la acest tratament. Dovezile arată că aderența scăzută la TARVc are consecințe grave asupra sănătății mamei și nou-născutului. S-a estimat că, dacă gravidele HIV pozitive au o aderență la TARVc de cel puțin 95\%, beneficiile terapiei sunt sporite, cu îmbunătăţirea rezultatelor virusologice, imunologice și clinice (10).

Aderența pacienților la tratament presupune o colaborare între aceștia și cadrele medicale și reprezintă angajarea și participarea corectă a pacientului la planul de tratament. $\mathrm{Cu}$ toate acestea, aderența la TARVc continuă să reprezinte o problemă majoră de sănătate publică. Diferite studii au arătat că o aderență bună la TARVc este elementul esențial pentru obținerea și menținerea supresiei virale. $O$ aderență scăzută la TARVc determină dezvoltarea rezistenței la medicamente a virusului (11).

Aderența crescută la TARVc în rândul gravidelor este asociată direct cu scăderea riscului de transmitere materno-fetală a infecției cu HIV, cu supresia încărcăturii virale HIV (ÎV-HIV) și cu speranța de viaţă crescută a mamei. În schimb, aderența scăzută la TARVc este asociată cu rezultate slabe ale tratamentului, apariția rezistenței, creșterea cheltuielilor de asistență medicală și decese ce ar putea fi evitate (12).
Principalii factori care pot influența negativ aderența la TARVc sunt: efectele adverse ale terapiei, stigmatizarea socială, depresia, nedivulgarea statutului de persoană HIV pozitivă, șomajul, abuzul de alcool/substanțe, forme alternative de terapie, epuizarea stocurilor de medicamente, distanța faţă de clinici $(13,14)$. Factorii asociați cu non-aderența variază, de asemenea, contextual (de exemplu lipsa educaţiei, vârsta mai tânără, mediul rural, lipsa spijinului financiar și emoțional din partea familei) (15).

Un factor important ce influențează aderența la TARVc este cunoașterea de către gravidă a statului HIV înainte de obținerea sarcinii.

Deși există posibilitatea unui risc mai crescut de naștere prematură în cazul gravidelor care primesc TARVc, beneficiile acestui tratament, atât pentru mamă, cât și pentru prevenirea transmiterii perinatale, justifică iniţierea și continuarea tratamentului în cursul sarcinii (16).

Obiectivele acestui studiu sunt evaluarea nivelului aderenței la TARVc a gravidelor infectate cu HIV-1 în copilăria mică, aflate în evidența Centrului Regional de Monitorizare și Evaluare a Infecției HIV/SIDA din cadrul Spitalului de Boli Infecțioase și Pneumoftiziologie „Victor Babeș“ Craiova (CRC) și identificarea principalilor factori asociați cu nonaderența.

\section{MATERIAL ȘI METODE}

Am realizat un studiu retrospectiv, în perioada 01 ianuarie 2014 - 31 decembrie 2019, analizând datele consemnate în documentele medicale ale gravidelor HIV pozitive aflate în evidența CRC.

Am evaluat datele demografice, datele epidemiologice, datele privind tratamentul antiretroviral (durata administrării, numărul și tipul de scheme utilizate), date furnizate de rezultatele chestionarului de aderență la TARVc și date referitoare la factorii ce au influențat aderența la TARVc.

Nivelul aderenței a fost apreciat după aplicarea unui chestionar de aderență: 18-22 puncte (aderență $\geq 80 \%$ ) și sub 18 puncte (nonaderenţă $<80 \%$ ) (17).

Pentru corelațiile statistice am utilizat testul Fisher, pragul de semnificație fiind considerat $\mathrm{p}<0,05$, iar pentru sintetizarea rezultatelor am utilizat tabele și figuri.

\section{REZULTATE}

Grupul studiat a cuprins 71 de paciente și a fost divizat în două loturi, în funcție de calea de infectare cu 
HIV: lotul A, ce a cuprins 48 de gravide infectate cu HIV pe cale parenterală, în copilăria mică și lotul B, ce a cuprins 23 de gravide infectate cu HIV pe cale sexuală.

Caracteristicile loturilor sunt prezentate în tabelul 1.

TABEL 1. Caracteristicile pacientelor din loturile studiate

\begin{tabular}{|c|c|c|c|c|}
\hline \multirow{2}{*}{$\begin{array}{c}\text { Caracteristicile } \\
\text { loturilor }\end{array}$} & \multicolumn{2}{|c|}{ Lot A } & \multicolumn{2}{c|}{ Lot B } \\
\cline { 2 - 5 } & Mediana & $\begin{array}{c}\text { Media } \pm \\
\text { DS }\end{array}$ & Mediana & $\begin{array}{c}\text { Media } \pm \\
\text { DS }\end{array}$ \\
\hline $\begin{array}{c}\text { Vârsta la } \\
\text { momentul } \\
\text { diagnos ă⿴囗十 } \\
\text { infecției cu HIV } \\
\text { (ani) }\end{array}$ & $13[3: 30]$ & $13,1 \pm 5,5$ & $\begin{array}{c}23 \\
{[14: 32]}\end{array}$ & $23,5 \pm 5$ \\
\hline $\begin{array}{c}\text { Vârsta la } \\
\text { momentul } \\
\text { sarcinii (ani) }\end{array}$ & 28 & $27,6 \pm 2,2$ & $\begin{array}{c}24 \\
{[14: 34]}\end{array}$ & $25,9 \pm 5$ \\
\hline $\begin{array}{c}\text { Durata de la } \\
\text { momentul } \\
\text { diagnos } \\
\text { până la } \\
\text { momentul } \\
\text { sarcinii (ani) }\end{array}$ & $15[0: 25]$ & $14,1 \pm 5,2$ & $1[0: 9]$ & $2,39 \pm 2,87$ \\
\hline
\end{tabular}

Mediana vârstei pacientelor la momentul diagnosticării infecției cu HIV a fost de 16 ani, cu diferențe statistic semnificative între cele două loturi $(\mathrm{p}=0,003)$.

Mediana duratei tratamentului a fost 12 ani [0:24], iar mediana numărului de regimuri terapeutice a fost 3 [1:8].

Pentru profilaxia transmiterii verticale a infecției cu HIV, au primit terapie antiretrovirală pe tot parcursul sarcinii 59 de paciente (83\%), fără diferențe statistic semnificative între cele două loturi $(p=0,2)$.

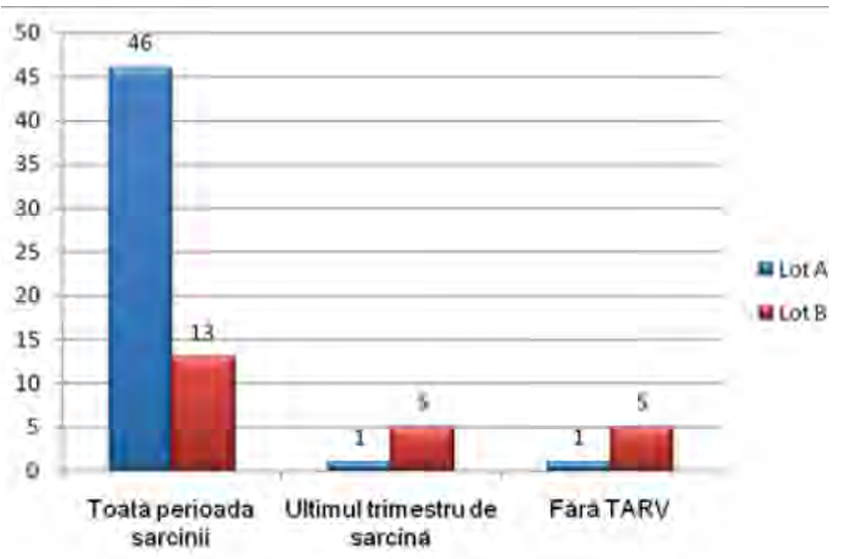

FIGURA 1. TARVc pe parcursul sarcinii

Dintre cele 6 paciente care nu au primit TARVc pe perioada sarcinii, o pacientă aparținând lotului A a refuzat tratamentul, iar celelalte 5 paciente, aparținând lotului B, au fost diagnosticate la momentul travaliului şi naşterii.
Cea mai utilizată schemă terapeutică în timpul sarcinii a fost Lamivudină/Zidovudină (ZDV/3TC) + Lopinavir/Ritonavir (LPV/r) - 20 paciente din lotul A $(42,5 \%)$ și 14 paciente din lotul B $(77,7 \%)$.

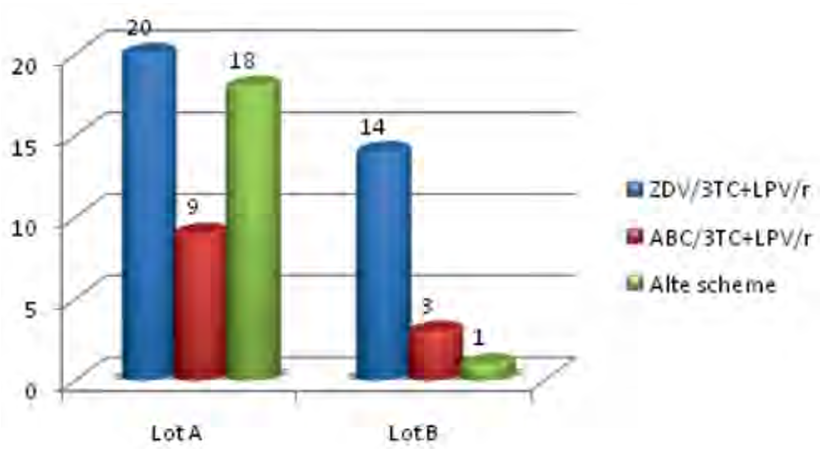

FIGURA 2. Scheme terapeutice utilizate pe parcursul sarcinii

Nivelul aderenței pacientelor din loturile studiate a fost evaluat prin aplicarea chestionarului de aderență la TARVc, ce este completat periodic de către toți pacienții HIV pozitivi aflați în evidența CRC.

Din totalul de 65 de paciente care au primit TARVc pe perioada sarcinii, 21 au prezentat nonaderență $(32,3 \%)$. Am constatat că proporția de paciente nonaderente la TARVc a fost mai mare în cadrul pacientelor infectate cu HIV pe cale sexuală $(77,7 \%)$, comparativ cu cele infectate parenteral, în copilăria mică $(14,8 \%), \quad$ cu diferențe semnificative statistic $(\mathrm{p}=0,001)$

Am identificat o parte dintre factorii care ar putea influența nivelul aderenței pacientelor la TARVc, comparând impactul acestora la pacientele aderente (aderență $\geq 80 \%$ ) vs pacientele nonaderente (aderență $<80 \%$ ).

Unul dintre cei mai importanţi parametri prin care poate fi evaluată aderența la TARVc este nivelul viremiei HIV. ÎV-HIV plasmatică nedetectabilă este o dovadă a eficienței schemei terapeutice, fiind corelată cu aderența. În cadrul studiului, am constatat o corelație înalt semnificativă statistic între ÎV-HIV şi nivelul aderenței la TARVc $(\mathrm{p}=0,005)$.

Evaluarea imunologică a gravidelor a evidențiat o imunodepresie uşoară, cu o medie a limfocitelor CD4 de $497,6 \pm 279,8$ celule $/ \mathrm{mm}^{3}, 43 \%$ dintre gravide având CD4 $>500$ celule $/ \mathrm{mm}^{3}$, fără diferențe statistic semnificative între cele două loturi $(p=1)$. Gradul imunodepresiei nu s-a corelat $\mathrm{cu}$ nonaderența la TARVc. 
Vârsta: ani

Data: Semnătura pacientului:

Semnătura evaluatorului:

1. Cât de mult crezi că administrarea zilnică, corectă şi fără întrerupere, conform recomandărilor medicului te ajută să-ţi păstrezi starea de sănătate? (alege o singură variantă de răspuns)
foarte mult 3
mult
puţin
deloc

2. Cum crezi că medicamentele anti-HIV îţi influenţează pozitiv viaţa? (alege una sau mai multe variante de răspuns): îmi asigură o stare bună de sănătate 3

îmi permit să am o viaţă îndelungată şi normală 3

scade riscul de transmitere a infecției la partener/ă 2

scade riscul de transmitere al infecţiei de la mine la viitorul meu copil 2

niciuna 0

3. Cum crezi că medicamentele anti-HIV îţi influenţează negativ viaţa? (alege o singură variantă de răspuns)

mi-e teamă că voi fi deconspirat (prin aspectul corporal, pot fi vazut cand imi iai medicamentele) 0

risc sa-mi pierd iubitul/a 0

îmi incurcă programul de viaţă 0

îmi amintesc permanent că sunt un om bolnav 0

îmi dau o stare de rău 0

niciuna 1

4. Ai sărit vreo administrare weekend-ul trecut?
$\mathrm{DaO}$
$\mathrm{Nu} 3$

5. Câte administrări ai omis in ultima lună? (alege o singură variantă de răspuns)

$\mathrm{N}$-am omis nici una 3

O singură administrare 3

Între 2 şi 4 administrări 2

Între 4 şi 8 administrări 1

Peste 8 administrări 0

6. În lunile trecute ţi s-a întâmplat la fel ca în ultima lună?

$$
\mathrm{Da}
$$

$\mathrm{Nu}$

7. Ţi s-a intâmplat să-ţi rămână medicamente în plus la sfârşitul lunii pentru ca nu ti-ai luat consecvent medicamentele ?
Da multe 0
Da putine 1
$\mathrm{Nu} 2$

8. Care administrare este cea mai dificilă? (alege o singură variantă de răspuns)
Cea de dimineaţă
Cea de la prânz/după masă
Cea de seară
Toate
Nici una

9. Ce faci pentru a-ţi aminti să iei pastilele (alege una sau mai multe variante de răspuns):

Îmi pun ceasul/telefonul să sune

Folosesc cutii speciale în care îmi pun numărul de pastile pe care urmează să le iau.

Îmi amintesc părinţii/partenerul/altcineva

Folosesc celelalte activităţi zilnice (de ex. mesele principale)

Nu am o metodă specială

Scorul evaluarii:

Cotare:

20-22 puncte = aderenta foarte buna, respectiv de $95 \%$

Min acceptat: 18 puncte = aderenta acceptabila, respectiv de $80 \%$

Sub 18 puncte $=$ nonaderenta, respectiv sub $80 \%$

FIGURA 3. Chestionar de evaluare a aderenței

Pacientele nonaderente la TARVc au fost consiliate de către psihologul $\mathrm{CRC}$, în vederea identificării cauzelor ce au dus la aderența scăzută și luării unor măsuri pentru îmbunătăţirea nivelului de aderenţă la TARVc. 


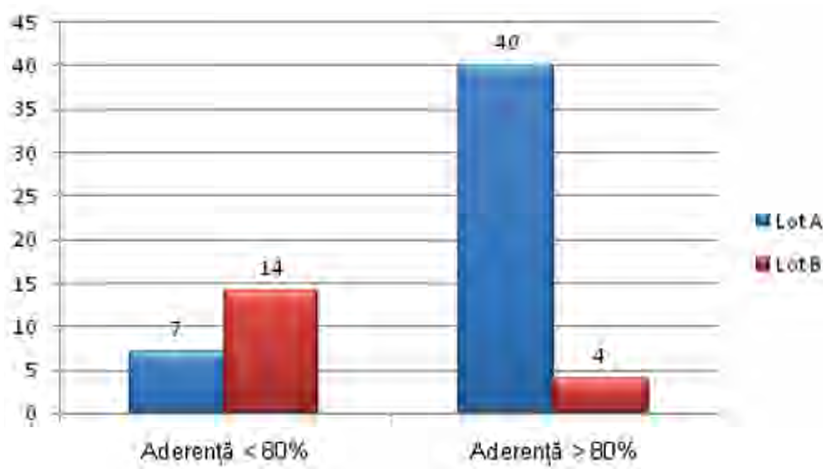

FIGURA 4. Nivelul aderenței la TARVc în cadrul celor două loturi

TABEL 2. Factorii ce pot influența aderența la TARVc

\begin{tabular}{|c|c|c|c|c|}
\hline \multicolumn{2}{|c|}{ Factorii ce pot influența aderența } & Aderență $<80 \%$ & Aderență $\geq 80 \%$ & $\mathbf{p}$ \\
\hline Școlarizare & $\begin{array}{l}<8 \text { clase } \\
\geq 8 \text { clase }\end{array}$ & $\begin{array}{c}14 \\
7\end{array}$ & $\begin{array}{c}6 \\
38 \\
\end{array}$ & 0,004 \\
\hline Mediul de proveniență & $\begin{array}{l}\text { rural } \\
\text { urban }\end{array}$ & $\begin{array}{c}16 \\
5\end{array}$ & $\begin{array}{l}31 \\
13\end{array}$ & 1 \\
\hline Statusul marital & $\begin{array}{c}\text { necăsătorite } \\
\text { căsătorite/relație stabilă }\end{array}$ & $\begin{array}{c}3 \\
18\end{array}$ & $\begin{array}{c}5 \\
39\end{array}$ & 1 \\
\hline Statusul socio-economic & $\begin{array}{c}\text { precar } \\
\text { bun }\end{array}$ & $\begin{array}{c}12 \\
9\end{array}$ & $\begin{array}{c}1 \\
43\end{array}$ & 0,002 \\
\hline $\begin{array}{l}\text { Vârsta la momentul } \\
\text { sarcinii }\end{array}$ & $\begin{array}{l}\leq 26 \text { ani } \\
>26 \text { ani }\end{array}$ & $\begin{array}{c}15 \\
6 \\
\end{array}$ & $\begin{array}{l}10 \\
34 \\
\end{array}$ & 0,01 \\
\hline Efecte adverse la TARVc & $\begin{array}{l}\text { Prezente } \\
\text { Absente }\end{array}$ & $\begin{array}{l}14 \\
7\end{array}$ & $\begin{array}{l}12 \\
32\end{array}$ & 0,04 \\
\hline
\end{tabular}

TABEL 3. Corelația între statusul imuno-virusologic și nivelul aderentei

\begin{tabular}{|c|c|c|c|c|}
\cline { 3 - 5 } \multicolumn{2}{l|}{} & $\begin{array}{c}\text { Aderență } \\
<80 \%\end{array}$ & $\begin{array}{c}\text { Aderență } \\
\geq 80 \%\end{array}$ & p \\
\hline \multirow{2}{*}{ ÎV-HIV } & $<50$ copii/ml & 4 & 32 & 0,005 \\
& $>50 \mathrm{copii} / \mathrm{ml}$ & 17 & 12 & \\
\hline \multirow{2}{*}{ CD4 } & $<200 \mathrm{cel} / \mathrm{mm}^{3}$ & 5 & 3 & \multirow{2}{*}{0,2} \\
& $>200 \mathrm{cel} / \mathrm{mm}^{3}$ & 16 & 41 & \\
\hline
\end{tabular}

\section{DISCUȚII}

Aderența la tratament ocupă un loc important în managementul pacienților HIV pozitivi. TARVc la gravida HIV pozitivă se indică pentru prevenirea transmiterii verticale a infecției şi pentru împiedicarea evoluţiei bolii materne. TARVc trebuie adaptat unui beneficiu matern maxim, luându-se în consideraţie şi beneficiul fetal $(18,19)$.

Studii din diverse zone ale lumii raportează mai mulţi factori care pot influenţa nivelul de aderență la TARVc, o parte dintre aceştia fiind evaluați şi în studiul pe care l-am efectuat.
Un studiu amplu a fost efectuat între 2001 și 2005 în centrele din Chicago, New York, Houston, Boston/ Worcester și San Juan, Puerto Rico, care a examinat utilizarea și aderența la TARV a gravidelor HIV pozitive în trimestrul al treilea de sarcină și la 6 luni postpartum. Aderența la TARVc a fost evaluată printr-o metodă de autoraportare. În trimestrul al treilea de sarcină, 61\% dintre paciente (188 din 309) au avut aderență completă la TARV, definită ca aderența la toate medicamentele administrate în ultimele două zile și fără doze omise în ultima lună. Factorii asociaţi cu nonaderența au inclus boala avansată maternă, încărcătură virală HIV mare, consumul de alcool și fumatul. La 6 luni postpartum, 55\% dintre paciente au prezentat aderență bună la TARVc. Rezultatele acestui studiu indică faptul că pacientele au prezentat o mai bună aderență la tratament în timpul sarcinii decât postpartum, probabil datorită motivației de a reduce riscul de transmitere verticală a infecției și/sau supravegherii intense antepartum (20).

În studiul pe care l-am efectuat, gravidele infectate cu HIV-1, pe cale parenterală, în copilăria mică, au 
avut o aderență crescută la TARVc în număr mai mare, comparativ cu cele infectate pe cale sexuală.

Un alt studiu efectuat în Africa de Sud (provincia Eastern Cape) a inclus 1.709 de gravide HIV pozitive. Dintre acestea, $69 \%$ au prezentat aderență foarte bună la TARVc. Statusul marital, fumatul, consumul de alcool și nedivulgarea statusului HIV au fost factori predictivi independenți ai non-aderenței. Analiza datelor calitative a relevat faptul că efectele adverse ale TARVc, stigmatizarea, uitarea administrării medicamentelor au fost principalele motive ale nonaderenței (12).

Au fost efectuate 51 de studii ce au implicat 20.153 de gravide HIV pozitive. Majoritatea studiilor au fost efectuate în Statele Unite ale Americii (27\%), Kenya (16\%), Africa de Sud (10\%) și Zambia (10\%). Pragul care a definit o bună aderență la TARVc a variat de-a lungul studiilor ( $>80 \%,>90 \%,>95 \%, 100 \%)$. O analiză comună a tuturor studiilor a indicat că aproximativ 73,5\% dintre gravide au prezentat o aderență bună (> 80\%). Proporția gravidelor cu aderență bună la tratament a fost mai ridicată în perioada antepartum

\section{BIBLIOGRAFIE}

1. https://www.who.int/news-room/fact-sheets/detail/hiv-aids. [Online] November 15, 2019. [Cited: August 19, 2020.].

2. Nthala V, Makasa M, Hazeemba A, Sitali D. Adherence to ART Among Pregnant Women Living with HIVIAIDS in Lusaka Urban. Journal of Public Health International. 2019;1(3).

3. European Guidelines for treatment of HIV-positive adults in Europe. October 2018.

4. The European Collaborative Study. Mother-to-child transmission of HIV infection in the era of highly active antiretroviral therapy. Clin Infect Dis. 2005;40:458-65.

5. Cooper ER, Charurat M, Mofenson $L$ et al. Combination antiretroviral strategies for the treatment of pregnant HIV-1-infected women and prevention of perinatal HIV-1 transmission. J Acquir Immune Defic Syndr. 2002;29:484-94.

6. Mandelbrot L, Tubiana R. No perinatal HIV-1 transmission from women with effective antiretroviral therapy starting before conception. Clin Infect Dis. 2015;61:1715-25.

7. Hampanda KM, Abuogi LL, Ahmed Y. HIV-Positive Women Taking Lifelong Antiretroviral Therapy Report Better Adherence Than Women Taking Short-Course Prophylaxis During and After Pregnancy Under PMTCT Program Option A in Lusaka, Zambia. International Journal of MCH and AIDS. 2017;6(1):28.

8. https://aidsinfo.nih.gov/guidelines/htm//3/perinatal/0. [Online] 2018. [Cited: August 19, 2020].

9. Gilbert EM, Darin KM, Scarsi KK, McLaughlin MM. Antiretroviral pharmacokinetics in pregnant women. Pharmacotherapy. 2015; 35:838-55.

10. Iliyasu Z, Kabir M, Abubakar IS, Babashani M, Zubair ZA. Compliance to antiretroviral therapy among AIDS patients in Aminu Kano Teaching Hospital, Kano, Nigeria. Niger J Med. 2005; 14(3):290-294.

11. Nachega JB, Marconi VC, van Zyl GU, GardnerEM, PreiserW, Hong SY et al. HIV treatment adherence, drug resistance, virologic failure: evolving concepts. Infect Disord Drug Targets. 2011;11:167-174.

12. Adeniyi OV, Ajayi Al, Ter Goon D, Owolabi EO, Eboh A, Lambert J. Factors affecting adherence to antiretroviral therapy among pregnant decât în cea postpartum. Factorii ce au determinat nonaderența au fost stresul emoțional, fizic și financiar, depresia (în special postpartum), consumul de acool sau droguri, povara administrării tratamentului (21).

În studiul nostru, am identificat următorii factori asociați cu aderența scăzută la TARVc: școlarizarea $(\mathrm{p}=0,004)$, statusul socio-economic $(\mathrm{p}=0,002)$, vârsta la momentul sarcinii $(\mathrm{p}=0,01)$ și efectele adverse la TARVc $(p=0,04)$.

\section{CONCLUZII}

Gravidele infectate cu HIV-1 în copilăria mică au avut un nivel crescut al aderenței, comparativ cu cele infectate pe cale sexuală.

Nivelul aderenței s-a corelat semnificativ statistic cu nivelul viremiei HIV.

Principalii factori asociați cu nonaderența au fost nivelul scăzut educaţional, statusul socio-economic precar, vârsta tânără la momentul sarcinii, prezența efectelor adverse la terapia antiretrovirală.

women in the Eastern Cape, South Africa. BMC Infect Dis. 2018; 18(1):175.

13. Shubber Z, Mills EJ, Nachega JB et al. Patient-Reported Barriers to Adherence to Antiretroviral Therapy: A Systematic Review and Meta-Analysis. PLoS Med. 2016;13(11):e1002183.

14. Azia IN, Mukumbang FC, Van Wyk B. Barriers to adherence to antiretroviral treatment in a regional hospital in Vredenburg, Western Cape, South Africa. Southern Afr. J HIV Med. 2016;17(1):1-8.

15. Mukui IN, Williamson J, Wamicwe JN et al. Rates and predictors of non-adherence to antiretroviral therapy among HIV-positive individuals in Kenya: Results from the second Kenya AIDS Indicator survey, 2012. PLoS One. 2016;11(12):e0167465.

16. Fowler MG, Qin M, Fiscus SA et al. Benefits and risks of antiretroviral therapy for perinatal HIV prevention. N Engl J Med. 2016; 375:1726-1737.

17. Drăgănescu $M$, lancu $A V$, Modrigan $M$, Arbune $M$. Aderența la tratamentul antiretroviral și trăsăturile de personalitate ale pacienților cu infecție HIV. Probleme de patologie infecțioasă la frontiere. Conferința Națională cu participare Internatională, Galați, 7-9 iunie 2018, Editura GUP, 2018.

18. Brocklehurst $P$. Interventions for reducing the risk of mother-to-child transmission of HIV infection. Cochrane Database Syst Rev. 2002.

19. Lyall EG, Blott M, de Ruiter A, Hawkins D, Mercy D, Mitchla Z et al. Guidelines for the management of HIV infection in pregnant women and the prevention of mother-to-child transmission. HIV Med. 2001; 2:314-34.

20. Mellinsa CA, Chub C, Maleec K et al. Adherence to antiretroviral treatment among pregnant and postpartum HIV-infected women. AIDS Care. 2008;20(8):958-968.

21. Nachegaa JB, Uthmane OA, Andersong J, Peltzer K et al. Adherence to antiretroviral therapy during and after pregnancy in low-income, middle-income, and high-income countries: A systematic review and meta-analysis. AIDS. 2012;26(16):2039-2052. 